\title{
State and the Struggle for Sustainable Livelihood: Implications of Large Dams on the Brahmaputra Valley in Assam
}

\author{
Priyanka Sharma \\ Assistant Professor, Centre for Women's Studies, Dibrugarh University, Dibrugarh-786004, Assam, India
}

\begin{abstract}
Hydro power generation has been considered as one of the major sectors for bringing about economic transformation for the North Eastern region of India. The potentialities of the region have been explored and the water resources are set to be tapped to meet the ever increasing demands of energy security. The execution of projects proposed and maintenance of the existing projects will prove to be a litmus test for the much hyped 'acche din' for the people of the region. Assam is a bio-diversity hotspot and exhibits a unique blend of cultures and traditions of diverse communities many of whom depend on Common Property Resources (CPR) for their livelihood. The paper explores the conflict that might arise from any such attempt that impinges on the right of the communities towards a secure livelihood.
\end{abstract}

Keywords: Sustainability, livelihood, development, dams, ecological crises, democratic state

\section{Introduction}

Human survival is dependent on the availability of natural capital as well as social and finance capital and when ecological imbalance and destruction of livelihood surface due to the disparaging attitude of the state in terms of its development policies, survival of mankind is at stake. The environment provides human societies with all the necessary ingredients to satisfy their needs and is instrumental for the advancement of the human civilization. Creation and access to livelihood opportunities is one such need which centres round the issue of right to life towards which every state has moral obligation. But such opportunities should not exhaust the natural resource base which is finite. Large dams are being favoured by the Indian state in order to tap the electricity generation capacity of the river Brahmaputra. But the havoc that such development policies can create in the lives of the people depriving them of their livelihood opportunities particularly in the downstream areas has not found due emphasis in the policy making process of the state. Sustainability of the livelihood base is thus crucial not only for the survival of mankind but also for the legitimacy behind stability of a democratic state.

\section{Aim}

The main objective of the paper is to focus on the issue of sustainability and the struggle for livelihood keeping in mind the debate over large dams in the Brahmaputra valley in Assam which needs to be evaluated not only from an economic perspective but also must take into cognizance the social and environmental factors.

\section{Methodology}

The research paper is exploratory in nature and draws inputs extensively from secondary sources viz. books, journals, reports, newspaper editorials, government reports etc. Content analysis constitutes a major method of analysis.

\section{State and Sustainable Livelihood: An overview}

State has been generally viewed as the legitimate authority entrusted with the responsibility of maintaining the socioeconomic and political order along with providing opportunities for the welfare and sustenance of livelihood of its citizens. Article 22 of the Universal Declaration of Human Rights, 1948 adopted by the United Nations, states that every member of the society has the 'right to social security and is entitled to realization, through national effort and international co-operation and in accordance with the organization and resources of each State, of the economic, social and cultural rights indispensable for his dignity and the free development of his personality.' [1] (Brownlie and Goodwin-Gill, 2007:27). The post-colonial developmental state model is based on the assumption that the state will be a 'secular' and 'democratic' state dedicated towards economic development, social justice and national unity and integrity. The relationship between the democratic state and socio-economic development is central to all states. However, with the growing emphasis on the rethinking of the concept of 'development' itself, states are increasingly directing their means to achieve the alternative dimensions of development as against only economic development understood in per capita income. The publication of the Human Development Reports by the UNDP, the popularity of the terms like human development and human security, gender equality, social development, cultural rights, sustainable development etc. have put the state in greater responsibility to fulfil these added criterions in order to secure its own legitimacy. Given the conditions of the democratic system and also the market realities particularly in the post 1990 period, the issue of 'state versus market' has come to dominate the political agenda of the states. Under a robust democratic system, it is undoubtedly the responsibility of the elected representatives to provide transparent and accountable services to the people. But at the same time, it is also the responsibility of the states to make the market system accountable so that inequalities are 


\section{International Journal of Science and Research (IJSR) \\ ISSN (Online): 2319-7064}

Index Copernicus Value (2013): 6.14 | Impact Factor (2015): 6.391

contained. Amit Bhaduri maintains that 'under the present conditions, it is not to be misunderstood that the state should follow only 'pro or contra-market' policies.' Instead "attempts should be made to devise policies through which both these institutions of the state and the market might reinforce one another for bringing our political and economic democracy closer." [2] (Bhaduri, Amit, 2005: 19).

Studies on livelihood security became popular in the late 1990s with growing emphasis on the issue of sustainability. Livelihood, in general, can be defined as adequate stocks and flows of food and cash to meet the basic needs of the people. The secure ownership of and access to resources and income - earning activities on a long term basis constitutes a livelihood. As a conceptual category, livelihood is interpreted in different ways at different levels. The traditional view of livelihood equates it with the set of activities, primarily economic, through which people earn a living. Relying mainly on poverty eradication, the Sustainable Livelihood approach attempts to go beyond the conventional definition of 'making a living' idea of livelihood towards a more integrated and holistic interpretation of the term. The most working definition of sustainable livelihoods was put forward by Chambers and Conway (1992; as cited by De Haan) who defined livelihood as "the capabilities, assets ( stores, resources, claims and access) and activities required for a means of living: a livelihood is sustainable which can cope with or recover from stress and shocks, maintain or enhance its capabilities and assets and provide sustainable livelihood opportunities for the next generation; and which contribute to net benefits to other livelihood at the local and global levels and in the short and long term" [3] (De Haan, 2012: 346). The Department for International Development (DFID) developed the Sustainable Livelihood Framework (SLF) which defines livelihood as comprising of assets (social, natural, physical, financial capital), strategies and contexts required for a means of living as well as the factors that make a livelihood more or less vulnerable to shocks and stress. The UNDP-IRP (India) conceives of a new term Livelihood Recovery as a tool of analysis within disaster response and recovery initiative. Commenting on Sustainable Livelihoods, L. Krantz [4] (2001) adds to the existing notion the need of building and enhancing the capacities of the poor to provide for themselves in order to take advantage of expanding economic activities and the need of target-group oriented programmes and follow-up studies for greater realisation of the objective of poverty reduction. The concept of livelihood has an inseparable relation with the process of development pursued by the state as it is through the development agenda (commonly understood as economic development) that the state utilises the resources available in order to create livelihood opportunities. Historically, the modernisation theorists have focussed on a top-down approach of development ignoring the 'human agency'. But with the failure of the centralised approaches to development, there is a renewed interest on a bottom-up, people - centric, participatory and more inclusive model trying to combine the livelihood approach with the ideas of social justice and equality. From an ecological perspective, it is held that the creation of livelihood opportunities must be compatible with the demands of maintaining a healthy environment as without a clean environment, the very issue of right to life of people is threatened. Creation of livelihood opportunities should be such that it does not exhaust the natural resource base which is finite. Livelihood is a complex system combining human, social, physical and financial resources to meet the requirements of the people in their day to day life as well as creating capabilities and assets in order to pursue a life of dignity both at the present and in the future.

\section{Implications of large dams on the Brahmaputra valley in Assam: Towards sustainable livelihood}

In the Indian context, the state followed the model of planned development immediately after independence with increased emphasis on accelerating economic growth in order to reorganise the economy of the country which was devastated by the colonial rule. Jawaharlal Nehru hailed as the architect of modern India favoured the use of technology and modern industries as the epitome of ushering the new nation towards development and modernity. According to A. Vaidyanathan, India has a greater need to tap the renewable supplies for agriculture due to its hot climate and high seasonal concentration of rainfall and the demand for domestic as well as non agricultural uses is rapidly growing [5] (Vaidyanathan, 2013: xi). Technological advances coupled with government policies have led to the rapid utilization of water resources through large dams, canal systems and groundwater management. The large scale mobilization of water for different purposes has, until recently, been seen as a welcoming gesture to meet the demands of the ever growing population. But of late, conflicts over water have risen with the growing evidence of the adverse effects of the existing water management policies through loss of cultivable land; displacement of communities; harm to flora and fauna; inability to maintain aquatic diversity; health related issues as well as intensification of water related conflicts due to growing scarcity of water [6] (Ibid, 2013). Post independence, water resource development and management was designated as a state subject by the Indian Constitution with the states requiring the Centre's approval for projects on inter -state rivers. However, it was soon realized that the Centre was more inclined towards larger projects than the minor irrigation projects which were left to be implemented and monitored by the states with little financial assistance. Subsequently, loss incurred on minor projects provided the justification behind the rationale favouring large projects.

Large dams are being favoured by the Indian state in order to tap the electricity generation capacity of the free flowing mighty Brahmaputra to the fullest. Since it has been established that the North East region of the country has the potential to generate about $38 \%$ of the country's total hydroelectric power potential, the Indian state is planning to convert NE India into a 'powerhouse' for India by tapping its hydropower potential to the maximum with the proposal of constructing not less than 168 big dams [7] (Vagholikar, Das, 2010: 1).

The majestic Brahmaputra river originates in the Tibetan plateau in the Kailash range of the Himalayas where it is 


\section{International Journal of Science and Research (IJSR) \\ ISSN (Online): 2319-7064 \\ Index Copernicus Value (2013): 6.14 | Impact Factor (2015): 6.391}

known by the name of Yarlung Tsangpo, flows eastward through China for about 700 miles and turns northeast and makes the Great Bend, enters India through Arunachal Pradesh where it is known as the Brahmaputra and flows through Bangladesh with the name of Jamuna and finally merges with the Bay of Bengal. North East India comprising of the states of Assam, Arunachal Pradesh, Meghalaya, Mizoram, Manipur, Tripura and Nagaland presents a unique blend of biological and cultural diversity accentuated by the beauty of the Brahmaputra and the Barak river systems. The region is rich in biodiversity and home to myriad wildlife species as well as aquatic and plant species.

The Brahmaputra is the lifeline of the region, particularly the state of Assam, cascading through the Himalayan slopes and deep gorges, alluvial plains and lowlands and is intricately linked to the flood plain ecology, nurturing and instilling life into the region. It is also one of the most diverse regions of the Indian sub- continent in terms of demography and the explanation lies in the region's distinct geographical location and the history of state formation. Different groups of people have migrated to Assam from different places at various points of time, producing a rich plurality of cultural forms. The diversified landscape of the region hosts a myriad of different communities, each with its own tradition, culture, practices etc. Throughout the pre-colonial, colonial and postcolonial period, this region has remained a difficult 'frontier' region. In economic terms, the region has also remained backward from the rest of mainstream India despite decades of economic planning although things are looking up in recent years. The uneven spatial distribution of resources and lack of development infrastructure have played the additional determining factors behind the already volatile atmosphere haunting the region in terms of ethnic violence. In such a scenario, any infrastructure project that is embedded with the policy of snatching away a substantial portion of livelihood opportunities of people who are dependent on natural resources, are bound to be met with public discontent, creating an upheaval in the politicoadministrative system of the state.

The 2000 MW Lower Subansiri Hydroelectric power project in Assam with a height of $116 \mathrm{~m}$, India's biggest so far; the Pagladia project, Kameng, Middle Siang (Arunachal Pradesh) and others have been at the centre of criticism in recent times for the potential adverse effects of the dams on the fragile ecology of the seismologically active region along with the potential negative effects on the life of the people displaced, depriving them of their livelihood opportunities and bringing in a permanent ecological crisis in the region.

The Kopili hydro electric plant, developed by the North Eastern Electric Power Corporation (NEEPCO) can be regarded as a major achievement in the realm of energy security scenario of the North eastern region of India exemplifying the development paradigm undertaken by the Indian state. However, as suggested by Sharma et al [8] (2011) although there were rare plant outages till 2006-07 since the commissioning of the power stations of the project, there have been reports of increasing outages since May, 2007. They observed that unsystematic coal mining in the upper catchment area of the Kopili has led to the exposure of the river water to organic sulphur leading to acidic contamination in the river which has become a major concern as it has serious repercussions not only for the life of the dam but also for the ecological balance of the region. Concerns over damming the river Kopili for development purposes reached a new height when the Lower Kopili Hydro Electric Power Project (LKHEP) was proposed in 2012. The project site is at Boro Longku village in Dima Hasao district and is to be developed by the Assam Power Generation Corporation Limited (APGCL). The catastrophic flood of 2004 in Assam that affected about 132 villages in the Kampur area of Nagaon district and other parts of Morigaon district and displaced about $1,92,000$ people is a perfect example of dam induced flood which was held to be a consequence of release of water from the Kopili reservoir [9] (SANDRP,2013). In such a situation construction of another dam in the same river might increase flood frequency in the downstream areas affecting thousands of people.

Menon argues that the central government and the proponents of large dams present a win win picture- exploit the country's perennial water resources to produce cheap, clean and plentiful of energy. The North Eastern states which have no substantial sources of revenue for their own expenditure see these projects as favourable for the speedy growth of their economy. 'Requiring no financial investment from their end, the states are looking to generate income through the sale of their share of free power to power companies.' Arunachal Pradesh in fact has identified hydropower as one of its major sources of revenue in the coming years as the construction of these projects will also lead to the development and improvement of infrastructure like roads and bridges. [10] (Menon, 2009: 129)

\section{Environment Effects}

The Brahmaputra river system is characterised by its glacial origin, located in a high seismic zone, heavy rainfall, flood prone rivers and high sedimentation rate. Any alteration with these characteristics is bound to bring catastrophes in the region. Dam induced flood can hamper agricultural activities in the region which can have severe implications for the livelihood of the downstream communities. North Eastern region is a geologically unstable area with frequent seismic activities. Bursting of the dam reservoirs during earthquakes cannot be ruled out which might create destruction beyond imagination. On the other hand, large dams cause significant changes in river hydrology, sediment load, riparian vegetation, submergence of land, destruction of fish species etc.

\section{Social Effects}

Communities depend on nature for their sustenance and have developed their culture, identity, social and economic systems around their natural resources. North East India, including Assam is dominated by mostly tribal communities who have their own system of land management and depend particularly on Community Property Resources (CPRs). But the land system that is being followed by the Indian state (as per the Land Acquisition Act, 1894) does not recognise community owned lands as they do not have individual 


\section{International Journal of Science and Research (IJSR) \\ ISSN (Online): 2319-7064 \\ Index Copernicus Value (2013): 6.14 | Impact Factor (2015): 6.391}

pattas. Only individual ownership of land is counted in calculating displacement. Hence, calculation of families to be displaced by projects often neglects those who depend on CPRs. For example, the Lower Subansiri dam counts only 38 families from 2 villages to be displaced and ignores 12 other villages that will be submerged by it. These 2 villages will lose more than 900 hectares of land but the state does not recognise their jhum cultivation land. So the 'land for land' rehabilitation scheme does not work for them and it also creates difficulty in getting compensation [11] (Fernandes, Barbora, 2009:3). What is ignored is the fact that although direct displacement of communities may be relatively smaller, but people to be 'affected' by the dam in the downstream areas will be high.

Shifting cultivation is one of the traditional forms of farming practised in the hill areas and plays a critical role in the livelihood of the people. Increasing pressure on land has led to the shortening of the jhum cycle and the submergence of land by hydro projects will enhance the pressure on the surrounding areas thereby affecting the environment and livelihood of the people. These im[acts have not been assessed nor accounted for in the EIA reports. Moreover, projects have been used as justification for preventing jhum cultivation which has been seen as a degraded method of agriculture. It is held that submergence of land may not be a great loss as these areas are already degraded by jhumming while compensatory mechanisms are seen as weaning people away from the practice of jhumming. [12] (Menon, 2009: 133). The implications of losing jhum land can be severe for the indigenous population as it could result in the loss of food security, loss of rights over traditional land and settled agriculture may not be a familiar practice in the hills. Customary tribal laws may be affected and it may ultimately lead to impoverishment of tribal communities.

On a similar note, traditional livelihood practices of various ethnic communities of Assam will be at stake due to the ecological imbalance that might surface because of dams. Protection of the rights of the people who mainly inhabit the region have been reiterated in view of the proposed Lower Kopili HEP apart from the resettlement and rehabilitation issues. Meeta Deka analyses that cultivation and fishing which are the major occupations of the people in which women are also engaged are at a greater risk due to the high acidic content of the Kopili river. Apart from creating health problems of the people, the toxic content in the river has also affected the health of crops and animals. She also remarks that women who are the 'agents of environmental sustenance' are the worst victims of this environmental degradation [13] (Deka, 2013:103). In its final report in case of the Lower Subansiri hydro electric project, the four member expert panel "refused" to give its consent for the construction of the $2000 \mathrm{MW}$ dam in its present form and design. [14] (The Assam Tribune, March 11, 2016)

\section{Large dams- An introspection}

Large dams have become a prominent instrument for economic development in the present day world. The World Commission on Dams Report [15] (2000) estimated that large dams contribute about 12-16\% of global food production. Besides, irrigation, they are definitely needed for the generation of hydroelectric power which is clean and non- polluting unlike thermal power plants. If properly designed and built, dams can actually aid economic and social development by performing the above mentioned functions through the two types of dams mainly: run-of-river dams which have very limited storage capacity and are built primarily for power generation and the storage dams for multiple purposes. Newly built dams are mostly storage dams which are more reliable and economical than run-ofriver dams but involve huge environmental and social costs.

These projects attract strong opposition due to large scale displacement of people and huge submergence of land, including forest cover, thereby, uprooting communities from their natural habitat and depriving them of their livelihood. The WCD report estimated that about 40-80 million people had been displaced by large dams while populations living in downstream of large dams have experienced serious turmoil through loss of livelihood opportunities which in turn have a direct bearing on their economic conditions and standard of life, thereby sucking them into the vicious poverty cycle through loss of food security as well as physical, cultural and spiritual security. River flows altered by dams often disrupt or destroy aquatic habitats bringing in hardships to river-dependent populations who rely on flood plain eco-systems for their livelihood.

Floods from the Kurishu dam in Bhutan and the Ranganadi dam in Arunachal Pradesh have wrecked havoc in the lives of the people in Assam, particularly the farming community. The hasty attitude of the central and state governments in implementing projects to tap the hydro electric power capacity of the Himalayan rivers of North east India has been met with severe resistance from the civil society. Terming such development agenda of the government as 'predatory development', Hiren Gohain warns of the impending calamity that the state seems to unleash on the people of the region [16] (Gohain, EPW, 2008:19).

Despite such experiences, the Indian state in alliance with private firms seems to be obsessed with large dam projects in order to generate 'hydro dollars' for the elite at the cost of the livelihood of the common man. What such a development model ignores is the fact that a large proportion of the population is displaced from their natural environment depriving them of their livelihood besides impinging on the communities' rights to resources as well as ecological damage. Even, the climate of the region has undergone tremendous changes with annual temperatures showing considerable variations while flood and drought have brought untold miseries to the people besides affecting the agricultural pattern of the state on which majority of the population depends for their livelihood. All such factors have led to serious degradation of the ecological balance of the region which can have drastic effects not only on the quality of life of the people but also on economic prosperity.

\section{Suggestions}

In view of the large scale destruction and threat to the natural habitat that large dams pose as well as the risk to human life, such planning measures of the state have faced sharp criticisms in recent times. Civil society organizations 


\section{International Journal of Science and Research (IJSR) \\ ISSN (Online): 2319-7064}

Index Copernicus Value (2013): 6.14 | Impact Factor (2015): 6.391

have strongly reacted against large damming projects which not only alter the environment but pose a severe threat to human life. Large dams may not always provide the fit all solution to problems like flood management or generation of electricity. Rather other alternatives may bring down the social and environmental costs that large projects involve.

It has been generally held that future wars among nations will not be based on arms but resources like water which has speed up the technology-driven planning for large projects in countries like China and India in order to meet the growing demand.

One such alternative to large projects is giving importance to local water harvesting and management schemes which can boost the supply side in view of the growing demand of water and the imminent water crisis set to hit the world in the coming decades.

Secondly, planning at the micro level will be more effective and people - oriented than planning at the macro level which seeks to overlook many social aspects.

Thirdly, water resource management should be given priority rather than water resource development. Specially, management at the local level should be stressed.

Fourthly, traditional methods of water conservation like canals, talabs etc should be revived for irrigation purposes.

Fifthly, planning measures such as preparation of EIA, environment clearance, rehabilitation and resettlement issues etc should be strictly adhered to.

Lastly, people's participation and cooperation at all levels should be properly ensured. Consultation with the project affected persons and their consent is a must before commissioning of large dam projects, if at all they are inevitable.

\section{Conclusion}

The potential adverse effects of dams on the fragile ecology of North East India which is also seismologically active along with the potential negative effects on the life of the people displaced might deprive them of their livelihood opportunities and bring in a permanent ecological crisis in the region. At a time when the whole world has turned towards a pledge for parity and sustainability, any attempt that might ignore the long term impact on livelihood stands at a contradiction to the state's responsibility towards sustainable development. Human survival is concomitant with the availability of natural resources and when ecological imbalance and destruction of livelihood surface due to the disparaging attitude of the state in terms of its development policies, survival of mankind is at stake.

\section{References}

[1] Brownlie, Ian and Guy S. Goodwin-Gill (ed) (2007). Basic Documents on Human Rights, Oxford University Press, Fifth Edition(Indian edition):New Delhi
[2] Bhaduri, Amit (2005). Development with Dignity: A Case for Full Employment, National Book Trust, India : New Delhi

[3] De Haan, Leo J. (2012). 'The Livelihood Approach: A Critical Exploration', Erdkunde, Vol 66, No 4, pp $345-$ 357

[4] Krantz, L. (2001). 'The Sustainable Livelihood Approach to Poverty Reduction: An Introduction', SIDA, pp 1-44

[5] Vaidyanathan, A. (2013). Water Resources in India, OUP: New Delhi

[6] Ibid

[7] Vagholikar,Neeraj and Partha J. Das(2010). Damming North East India, Kalpavriksh, Aaranyak and ActionAid India.

[8] Sharma, Pankaj, Sameer Vyas et al (2011). Acid Mine Discharge- Challenges Met in a hydro power project. International Journal of Environmental Sciences. Vol 1, No 6, pp 1274-1282

[9] SANDRP.(2013). Lower Kopili HEP: Outstanding issues must be resolved. http://sandrp.in

[10]Menon, Manju (2009). 'Land Alienation due to large Hydro-Power projects in Arunachal Pradesh' in Fernandes, Walter and Sanjay Barbora (ed). (2009). Land, people and Politics: Contest over Tribal Land in North East India. NESRC: Guwahati and IWGIA : Denmark Pp 128-141

[11]Fernandes, Walter and Sanjay Barbora(2009). 'Tribal Land Alienation in the North East: An Introduction' in Fernandes, Walter and Sanjay Barbora (ed). (2009). Land, people and Politics: Contest over Tribal Land in North East India. NESRC: Guwahati and IWGIA : Denmark, pp 1-15

[12] Menon, Manju (2009). 'Land Alienation due to large Hydro-Power projects in Arunachal Pradesh' in Fernandes, Walter and Sanjay Barbora (ed). (2009). Land, people and Politics: Contest over Tribal Land in North East India. NESRC: Guwahati and IWGIA : Denmark Pp 128-141

[13] Deka, Meeta (2013). Women's Agency and Social Change: Assam and Beyond, New Delhi: Sage

[14] The Assam Tribune, March 11, 2016

[15] World Commission on Dams Report (2000). London and Sterling, VA: Earthscan Publications Ltd

[16] Gohain, Hiren (2008): 'Big Dams, Big Floods: On Predatory Development', Economic and Political Weekly, July 26, pp 19-21 